\title{
Comparative inelastic analysis of RCC and steel-concrete composite frame
}

\author{
S.R.Sutar ${ }^{1}$, P.M.Kulkarni ${ }^{2}$ \\ ${ }^{I} P$ G Student, Civil Engg. Department, KJ's Trinity College of Engineering \& Research, Pune, India \\ ${ }^{2}$ Asst. Prof., Civil Engg. Department, KJ's Trinity College of Engineering \& Research, Pune, India
}

\begin{abstract}
The majority of building structures are designed and constructed in reinforced concrete which are mainly depends upon availability of the constituent materials and the level of skill required in construction, as well as the practicality of design codes. R.C.C is no longer economical because of their increased dead load, hazardous formwork. However composite construction is a new concept for construction industry. The use of modern composite systems, allowing the erection of multi-story structural frames to proceed at pace. The reviews shows that, the composite structures are best suited for high rise buildings compared to that of steel and reinforced concrete structures. Unfortunately, many of the available nonlinear analysis programs are only suitable for modeling traditional steel or reinforced concrete systems and are not directly applicable to composite frames. Part of this work presented herein is aimed to understand the nonlinear behavior of composite frame using ETAB 9.7.
\end{abstract}

Keywords: composite column, composite frame, nonlinear static analysis, pushover analysis

\section{Introduction}

Recent trends in construction industry is to use of steel, reinforced concrete and composite steelconcrete member which are functioning together and termed as composite, mixed or hybrid systems. Such systems make use of each type of member in most efficient manner to maximize the structural and economic benefit. An additional benefit provided by composite frame is derived from their excellent fire-resistant properties. Over the past twenty years the composite RCS moment frame systems have been used in the US and Japan. Extensive research is currently underway to better understand the behavior of such frames. Much of this research aims at experimentally investigating the characteristics of joints between steel and reinforced concrete members and understanding the behavior of mixed assemblies. On the other hand; System behavior has been much less researched and is not yet well understood. In Japan, however, the superior earthquake resistant properties of composite beam-columns have been long recognized and have become a commonly used form of construction in that region. In view of the growing popularity and use of composite systems, there is need for analysis of frame. And nonlinear analysis is a suitable tool for better understanding the behavior of systems, especially when subjected to dynamic excitation, unfortunately, many of the available analysis programs are only suitable for modeling traditional steel or reinforced concrete systems and are not directly applicable to composite frames. Part of this work presented herein is aimed to understand the nonlinear behavior of composite frame using ETAB v9.7.

Following are the objectives of proposed work

\section{Objectives}

1. To perform inelastic i.e. nonlinear static pushover analysis of Steel-Concrete Composite frame (encased rolled steel section in concrete and concrete filled steel section) using E-tab 9.7.

2. To study the performance of steel-concrete composite section w.r.t. different parameters such as story drift, story displacement, base shear, shear force etc.

3. To study the hinge formation during the performance of composite frame to verify strong column weak beam behavior of the members.

\section{Elements Of Composite Multistoried Buildings}

The primary structural components used in composite construction consists of

A. Composite deck slab

B. Composite beam

C. Composite column

D. Shear connector 


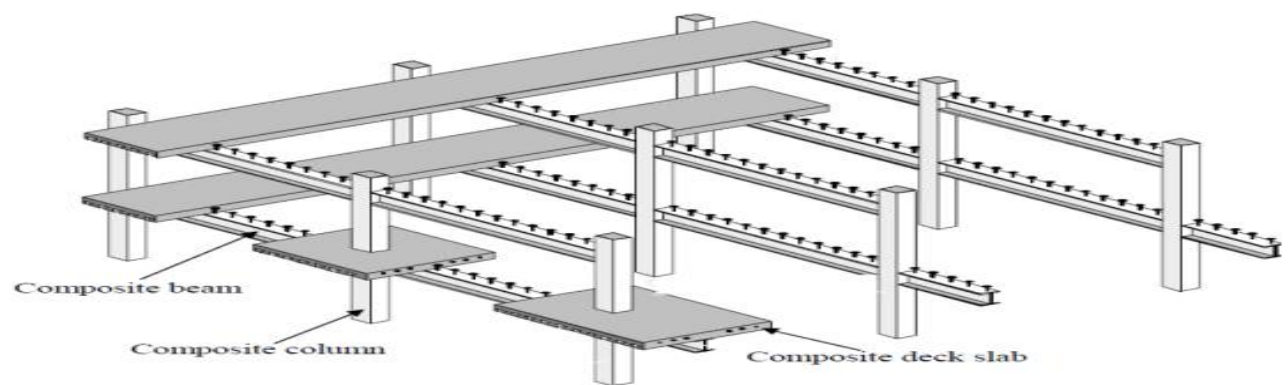

Fig 1. Typical Composite Frame

\subsection{Composite deck slab}

Recently in western countries, profiled deck sheeting is much popular in composite floor construction. Composite deck slabs are more suitable where the concrete floor has to be completed quickly and where medium level of fire protection to steel work is sufficient. But, composite slabs with profiled decking are unsuitable when there is heavy concentrated loading or dynamic loading in structures such as bridges. A typical composite floor system using profiled sheets is shown in Fig.2. There is presently no Indian standard covering the design of composite floor system using profiled sheeting.

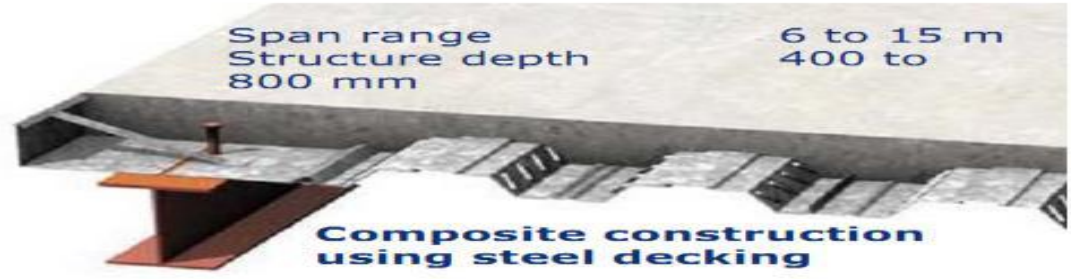

Fig. 2. Typical Composite Slab

\subsection{Composite beam}

Conventionally in composite construction, concrete slabs rest over steel beams and are supported by beams. Under loading condition these elements act independently if there is no any interface connection. Hence providing the interface connection both elements act as a monolithically. In this case the steel beam and the slab act as a "composite beam" and their action is similar to that of a monolithic Tee beam. By the composite action between these two elements, we can utilize their respective advantage to the fullest extent.

\subsection{Composite column}

It is a compression member consisting either concrete encased hot rolled steel section or a rolled steel section embedded in concrete. At present there is no Indian standard code covering the design of composite column. The design method follows largely follows Euro code 4, which provides latest research on composite construction. IS 11384-1985 does not make any specific provisions to composite columns.

\subsection{Shear connectors}

The total shear force at the interface between concrete slab and steel beam is approximately eight times the total load carried by the beam. Therefore, mechanical shear connectors are required at the steel-concrete interface. These connectors are designed to (a) transmit longitudinal shear along the interface, and (b) Prevent separation of steel beam and concrete slab at the interface.

\section{Literature Reviews}

J.M. Castro, A.Y. Elghazouli and B.A. Izzuddin (2008) Several sensitivity and parametric investigations are undertaken using an advanced analysis program that accounts for material and geometric nonlinearities. This paper assesses the inelastic seismic performance of composite steel/concrete momentresisting frames. The parametric investigation shows that several parameters and assumptions can have direct implications on the inelastic behavior of composite frames, as assessed through the overall lateral response, inter-storey drift distribution and plastic hinge patterns. And also a number of geometric parameters, related to the structural configuration, including beam span and structural height, have a significant influence on the behavior.

Keh-Chyuan TSAI, Yuan-Tao WENG, Sheng-Lin LIN, and Subhash GOEL (2004) this paper describing a full-scale 3-story 3-bay CFT buckling restrained braced frame (CFT/BRB) specimen that was 
constructed and tested in the structural laboratory. Pre-test nonlinear dynamic analyses suggest that the peak story drift is likely to reach 0.025 radian after applying the $2 / 50$ design earthquake on the frame specimen. CFT columns hinging at the base are expected, but should not fail as the rotational demand is moderate. Tests confirmed that the PISA3D and OpenSees analyses predicted the experimental peak shears extremely well. Tests also confirmed that experimental peak inter-story drifts of 0.019 and 0.023 radians well agree with the target design limits of 0.02 and 0.025 radians prescribed for the 10/50 and 2/50 events, respectively

S. Gramblicka, S. Matiasko (2009) in this work the theoretical analysis was made with respect to the current applicable European standards, which were compared with the experimental results of the columns tested and a non-linear analysis using Atena software. The values of the non-linear analysis of the composite columns with the use of the real measured material properties indicate a very good match with the tested columns, the experimental results can be used for further research of composite steel-concrete columns.

Eiichi Inai, Akiyoshi Mukai, Makoto Kai, Hiroyoshi Tokinoya, Toshiyuki Fukumoto, and Koji Mori (2004) In this paper the behavior of concrete-filled circular and square steel tubular (CFT) beam columns with a variety of material strengths was investigated experimentally. The interior beam-column models were tested under constant axial compression and cyclic horizontal load with incrementally increasing lateral deformation to clarify the effects of the test parameters on the behavior. The test results show that higher strength and thicker steel tubes give better overall behavior of the beam column, while higher strength concrete has an adverse effect on the behavior.

A. Zona, M. Barbato \& J. P. Conte The work provides the deeper insight into the nonlinear seismic response behavior of SCC frame structures and how it is influenced by various modeling assumptions. The results show that the inelastic partial composite action in the SCC frame structures..

Sherif El-Tawil,1 Member, ASCE, and Gregory G. Deierlein,2 Fellow This paper presents the formulation for a plasticity-based distributed beam-column element that can be used for the seismic analysis of three-dimensional mixed frame structures comprised of steel, reinforced concrete, and composite members.

From the above literature review it is seen that; in the western countries like USA, Japan, and Germany etc. much of research work is carried out in the field of composite construction. Some of research work conducted on the experimental design \& analysis of composite element such as encased section or in filled section considering linear and nonlinear behavior of structure. Also FE formulation of steel-concrete composite element is conducting in relevant field. But software based analysis of steel-concrete frame was very rarely examined. Hence there is scope in analyzing the steel-concrete composite frame using soft wares. So as part of dissertation, inelastic analysis (pushover analysis) for different types of steel-concrete frame is conducting using software application (E-tab 9.7).

\section{Methodology}

RCC \& Steel-concrete composite fame models (encased \& unfilled) are analyzed. FTS column (Concrete filled Tube) with RC Beam, EIS column (Encased I- section) with RC beam, ETS column (Encased Tube Section) with RC beam are modeled. And Inelastic analysis i.e. nonlinear static pushover analysis of both RCC \& steel-concrete composite frame are carried out using software tool ETAB 9.7. Different parameters such as shear force, story drift, story displacement \& performance points of both RCC \& composite frame are discussed. Study the hinge formation in both the frame which verifies the capacity based design of structure.

\subsection{Modeling of structure}

The proposed model presented herein is the existing multistoried $(\mathrm{G}+13)$ office building located in Pune city. The analysis of this building is carried out by creating the different composite column along with RC beam. The different composite columns created using ETAB v9.7 are as shown in fig.
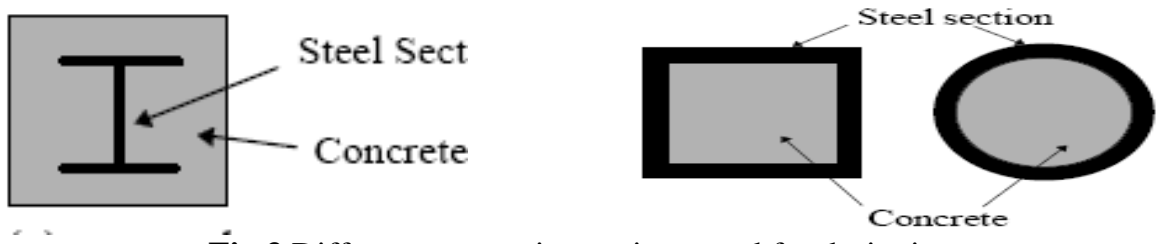

Fig.3.Different composite cestions used for designing

The composite column is design by using following equations,

For concrete encased and partially concrete encased sections

$\mathrm{P}_{\mathrm{PC}}=\mathrm{Aa} * \mathrm{fyd}+0.85 \mathrm{Ac} * \mathrm{fcd}+\mathrm{As} * \mathrm{fsd} \ldots \ldots . . \mathrm{Eq}-1$

For concrete filled sections

$\mathrm{P}_{\mathrm{PC}}=\mathrm{Aa} * \mathrm{fyd}+\mathrm{Ac} * \mathrm{fcd}+\mathrm{As} * \mathrm{fsd} \ldots \ldots \ldots \ldots . . . \mathrm{Eq}-2$

Where, 
Aa - cross sectional area of structural steel

Ac - cross sectional area of concrete

As - cross sectional area of reinforcing steel

fyd - design value of yield strength of structural steel

fcd - design value of yield strength of cylindrical compressive strength of concrete

fsd - design value of yield strength of reinforcing steel

The details of RCC \& composite frame are given in following table which is helpful in analysis of frame.

Table.1. Frame detailing required for analysis

\begin{tabular}{|l|l|l|}
\hline Particulars & RCC structure & Composite structure \\
\hline Plan dimension & $30 \mathrm{mx} 48 \mathrm{~m}$ & $30 \mathrm{mx} 48 \mathrm{~m}$ \\
\hline Height of each story & $3.97 \mathrm{~m}$ & $3.97 \mathrm{~m}$ \\
\hline Total height & $49.64 \mathrm{~m}$ & $49.64 \mathrm{~m}$ \\
\hline Depth of footing & $2 \mathrm{~m}$ & $2 \mathrm{~m}$ \\
\hline Size of beam & $300 \times 750$ & $300 \times 750$ \\
\hline \multirow{2}{*}{ Size of column } & $600 \mathrm{mmx} 600 \mathrm{~mm}$ & \multirow{2}{*}{ Encased I section } \\
\cline { 2 - 3 } & $750 \mathrm{mmx} 750 \mathrm{~mm}$ & \\
\cline { 2 - 3 } & $900 \mathrm{~mm} 900 \mathrm{~mm}$ & - \\
\hline Slab thickness & $150 \mathrm{~mm}$ & $2 \mathrm{kn} / \mathrm{m} 2$ \\
\hline Dead load & $2 \mathrm{kn} / \mathrm{m} 2$ & $4 \mathrm{kn} / \mathrm{m} 2$ \\
\hline Live load & $4 \mathrm{kn} / \mathrm{m} 2$ & III \\
\hline Seismic zone & III & Medium \\
\hline Soil condition & Medium & 5 \\
\hline Response reduction factor & 5 & 1 \\
\hline Importance factor & 1 & 0.16 \\
\hline Zone factor & 0.16 & $\mathrm{M} 30$ \\
\hline Grade of concrete & $\mathrm{M} 30$ & Fe250 \\
\hline Grade of steel & Fe500 & $5 \%$ \\
\hline Damping ratio & $5 \%$ & \\
\hline
\end{tabular}

\section{Results And Discussion}

Comparative inelastic analysis of both RCC \& Composite frame building is carried out using E-tab 9.7. The outcome from the analysis is described in this chapter and comparative analysis is discussed.

\subsection{Pushover analysis for RCC.}

Table no2. Story displacement $(\mathrm{mm}) \&$ drift $(\mathrm{mm})$ for RCC

\begin{tabular}{|l|r|r|r|r|}
\hline STORY & \multicolumn{1}{|c|}{ DISP-X } & \multicolumn{1}{|c|}{ DISP-Y } & \multicolumn{1}{|c|}{ DRIFT-X } & \multicolumn{1}{|c|}{ DRIFT-Y } \\
\hline STORY13 & -0.271543 & 0.00118 & 0.006756 & 0.000031 \\
\hline STORY12 & -0.24472 & 0.001057 & 0.006831 & 0.000031 \\
\hline STORY11 & -0.217602 & 0.000933 & 0.006872 & 0.000031 \\
\hline STORY10 & -0.19032 & 0.000808 & 0.006877 & 0.000031 \\
\hline STORY9 & -0.163019 & 0.000684 & 0.006812 & 0.00003 \\
\hline STORY8 & -0.135977 & 0.000565 & 0.006648 & 0.000029 \\
\hline STORY7 & -0.109584 & 0.000451 & 0.006357 & 0.000026 \\
\hline STORY6 & -0.084348 & 0.000346 & 0.005909 & 0.000024 \\
\hline STORY5 & -0.06089 & 0.000252 & 0.005275 & 0.00002 \\
\hline STORY4 & -0.03995 & 0.000171 & 0.004424 & 0.000017 \\
\hline STORY3 & -0.022386 & 0.000103 & 0.003328 & 0.000014 \\
\hline STORY2 & -0.009175 & 0.000048 & 0.001999 & 0.00001 \\
\hline STORY1 & -0.001239 & 0.000007 & 0.000619 & 0.000003 \\
\hline
\end{tabular}

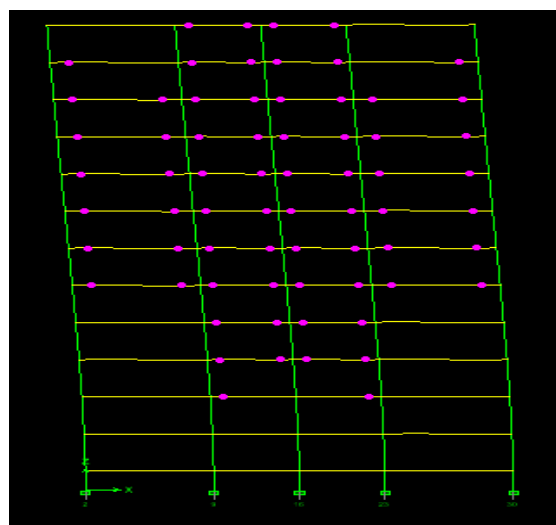

Fig.4. Hinge formation during deformation of RCC frame within elastic limit 


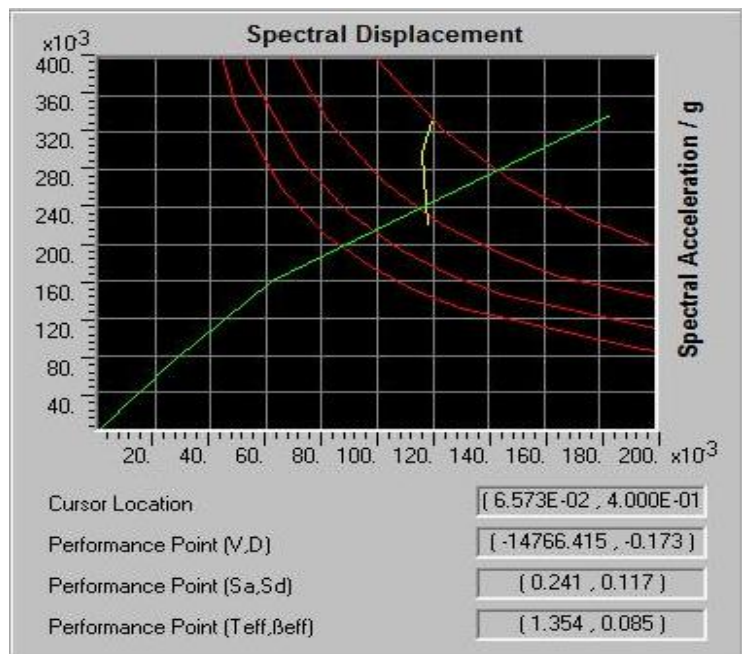

Fig.5. Performance Point of RCC frame model

The above results show the pushover analysis of RCC framed structure. The table no.2 gives the story displacement \& story drift for respective floor.

1.5. (EIS-RC, ETS-RC, FTS-RC) composite frame.

1.5.1. Results of EIS-RC (Encased I-Section column with RC beam) composite frame

1.5.1.1. Pushover analysis of EIS-RC composite frame

Table no.3. Story displacement $(\mathrm{mm}) \&$ drift $(\mathrm{mm})$ for RCC EIS-RC

\begin{tabular}{|l|r|r|r|r|}
\hline STORY & \multicolumn{1}{|c|}{ DISP-X } & \multicolumn{1}{|c|}{ DISP-Y } & \multicolumn{1}{c|}{ DRIFT-X } & \multicolumn{1}{c|}{ DRIFT-Y } \\
\hline STORY13 & -0.268392 & 0.00111 & 0.006674 & 0.000031 \\
\hline STORY12 & -0.241895 & 0.000985 & 0.006748 & 0.000032 \\
\hline STORY11 & -0.215106 & 0.00086 & 0.00679 & 0.000031 \\
\hline STORY10 & -0.188151 & 0.000736 & 0.006795 & 0.000031 \\
\hline STORY9 & -0.161174 & 0.000613 & 0.006732 & 0.00003 \\
\hline STORY8 & -0.134449 & 0.000495 & 0.006571 & 0.000028 \\
\hline STORY7 & -0.108361 & 0.000384 & 0.006284 & 0.000025 \\
\hline STORY6 & -0.083412 & 0.000283 & 0.005842 & 0.000022 \\
\hline STORY5 & -0.060218 & 0.000194 & 0.005216 & 0.000019 \\
\hline STORY4 & -0.03951 & 0.00012 & 0.004376 & 0.000015 \\
\hline STORY3 & -0.022139 & 0.000062 & 0.003294 & 0.00001 \\
\hline STORY2 & -0.009062 & 0.000022 & 0.001981 & 0.000005 \\
\hline STORY1 & -0.001199 & 0.000003 & 0.000599 & 0.000001 \\
\hline
\end{tabular}

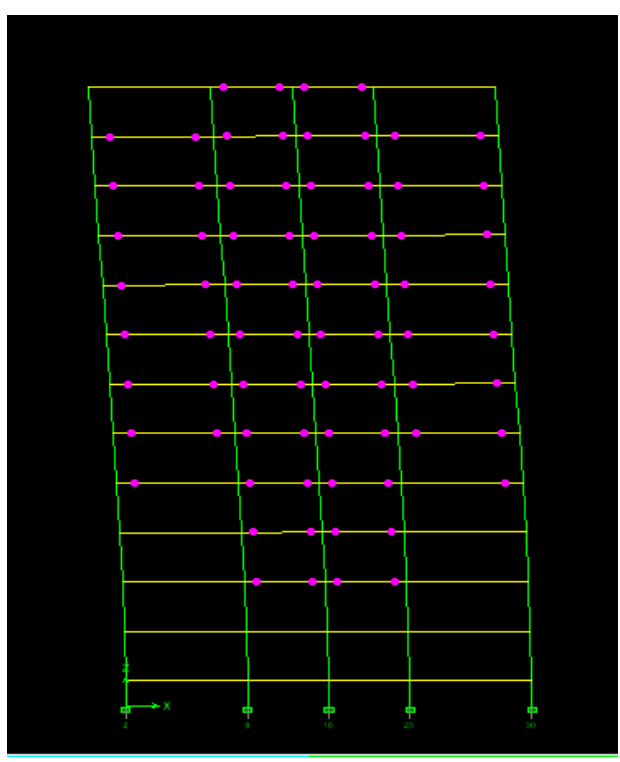

Fig.6.Hinge formation of EIS-RC at elastic limits

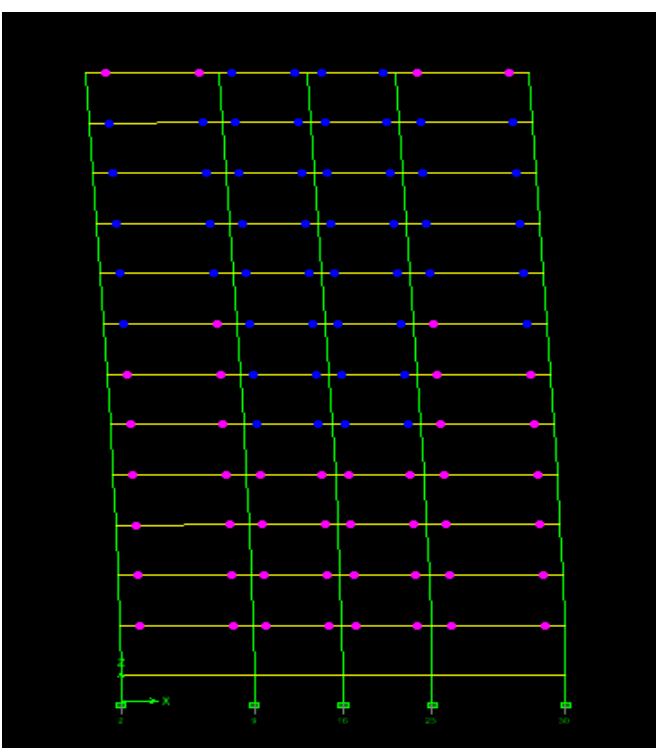

Fig.7. Hinge formation of EIS-RC at yield point 
1.5.1.2. Capacity spectrum curve or performance point of EIS-RC composite frame

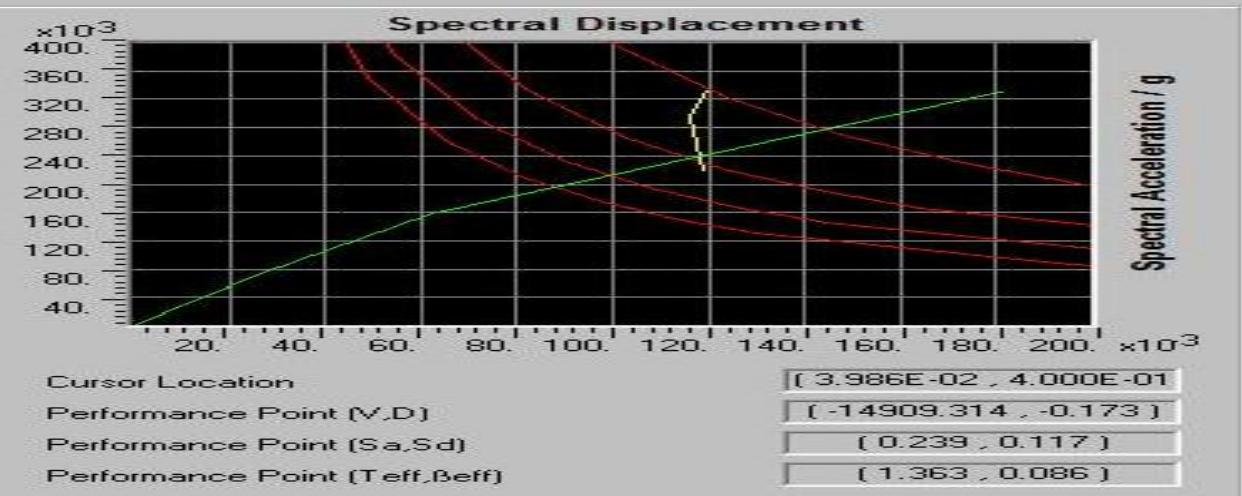

Fig.8. Capacity curve for EIS-RC frame

\subsubsection{3-D model of EIS-RC composite frame in E-tab 9.7}

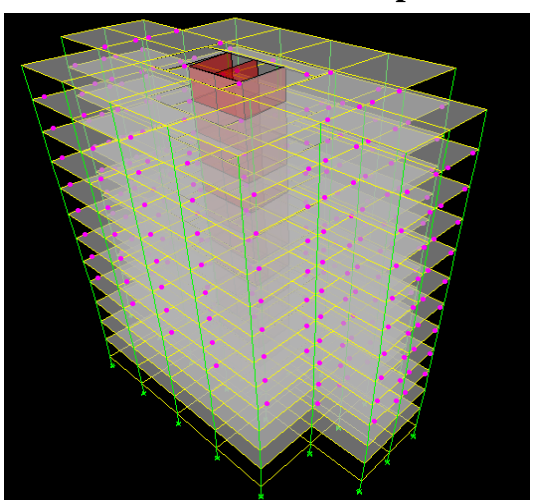

Fig.9. EIS-RC frame at elastic limit

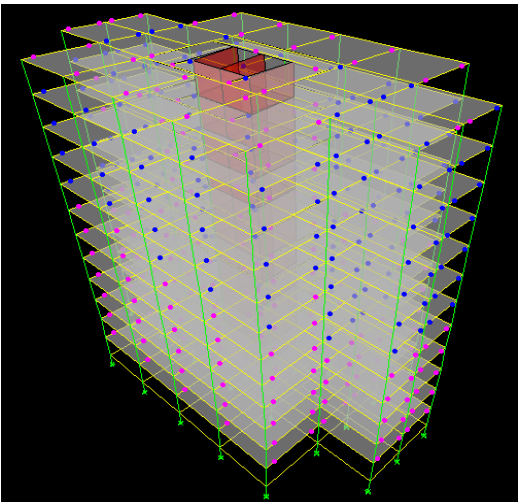

Fig.10. EIS-RC frame at yield point

1.6. Results for ETS-RC (Encased Tube Section column with RC beam) composite frame 1.6.1. Pushover analysis of ETS-RC frame.

Table no.4. Story displacement $(\mathrm{mm}) \&$ drift $(\mathrm{mm})$ for ETS-RC

\begin{tabular}{|l|c|c|r|r|}
\hline STORY & DISP-X & DISP-Y & DRIFT-X & \multicolumn{1}{|c|}{ DRIFT-Y } \\
\hline STORY13 & -0.268423 & 0.001088 & 0.006673 & 0.00003 \\
\hline STORY12 & -0.241932 & 0.000967 & 0.006747 & 0.00003 \\
\hline STORY11 & -0.215146 & 0.000846 & 0.006789 & 0.000031 \\
\hline STORY10 & -0.188194 & 0.000725 & 0.006795 & 0.00003 \\
\hline STORY9 & -0.161219 & 0.000605 & 0.006732 & 0.000029 \\
\hline STORY8 & -0.134494 & 0.000489 & 0.006571 & 0.000028 \\
\hline STORY7 & -0.108405 & 0.000379 & 0.006285 & 0.000025 \\
\hline STORY6 & -0.083454 & 0.000279 & 0.005843 & 0.000022 \\
\hline STORY5 & -0.060256 & 0.000191 & 0.005218 & 0.000018 \\
\hline STORY4 & -0.039542 & 0.000118 & 0.004377 & 0.000014 \\
\hline STORY3 & -0.022164 & 0.000061 & 0.003295 & 0.00001 \\
\hline STORY2 & -0.009082 & 0.000022 & 0.001985 & 0.000005 \\
\hline STORY1 & -0.001202 & 0.000003 & 0.000601 & 0.000001 \\
\hline
\end{tabular}

Capacity curve or pushover point of ETS-RC

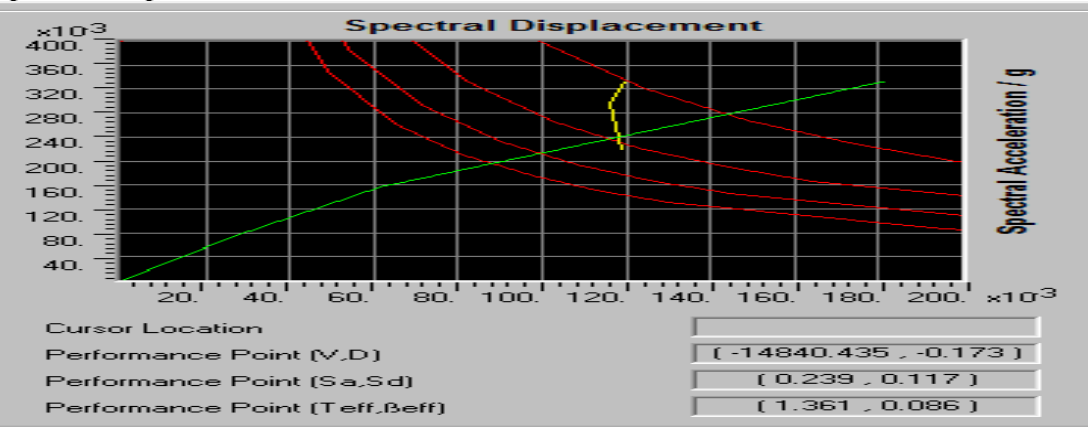

Fig.11. Capacity curve of ETS-RC frame 


\subsubsection{3-D model of ETS-RC frame}

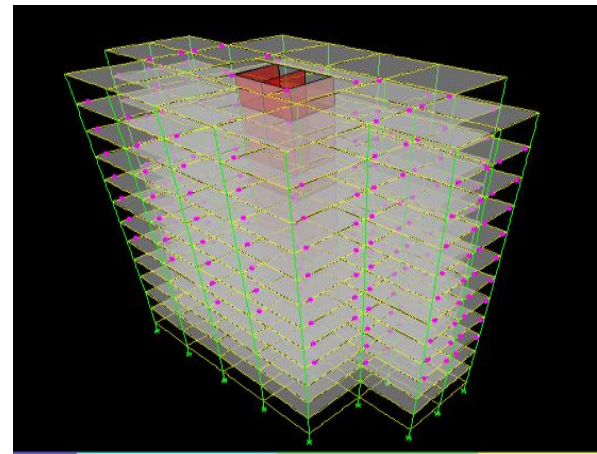

Fig.12. ETS-RC frame at elastic limit

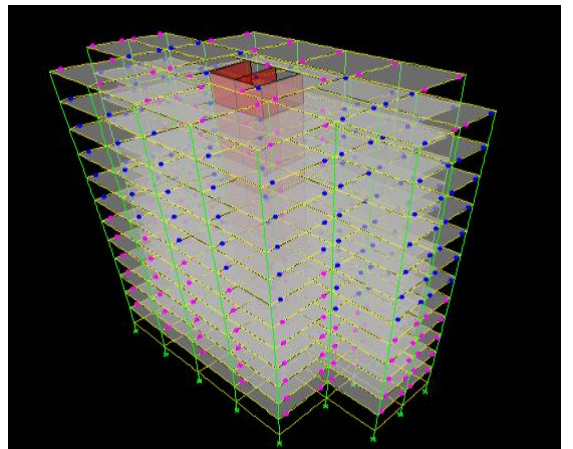

Fig.13. ETS-RC frame at yield point

1.7. Results for FTS-RC (Concrete Filled Tube Section with RC beam) composite frame

1.7.1. Pushover analysis of FTS-RC frame

Table no.5. Story displacement $(\mathrm{mm}) \&$ drift $(\mathrm{mm})$ for FTS-RC

\begin{tabular}{|l|r|r|r|r|}
\hline STORY & \multicolumn{1}{|c|}{ DISP-X } & \multicolumn{1}{c|}{ DISP-Y } & \multicolumn{1}{c|}{ DRIFT-X } & \multicolumn{1}{c|}{ DRIFT-Y } \\
\hline STORY1 & 0.00119 & 0.000003 & 0.000593 & 0.000001 \\
\hline STORY2 & 0.00904 & 0.000022 & 0.001978 & 0.000005 \\
\hline STORY3 & 0.02212 & 0.00006 & 0.003296 & 0.00001 \\
\hline STORY4 & 0.03951 & 0.000117 & 0.004379 & 0.000014 \\
\hline STORY5 & 0.06024 & 0.00019 & 0.005222 & 0.000018 \\
\hline STORY6 & 0.08347 & 0.000278 & 0.00585 & 0.000022 \\
\hline STORY7 & 0.10846 & 0.000377 & 0.006294 & 0.000025 \\
\hline STORY8 & 0.13459 & 0.000486 & 0.006583 & 0.000027 \\
\hline STORY9 & -.16137 & 0.000602 & 0.006745 & 0.000029 \\
\hline STORY10 & -0.1884 & 0.000722 & 0.00681 & 0.00003 \\
\hline STORY11 & 0.21542 & 0.000844 & 0.006806 & 0.000031 \\
\hline STORY12 & 0.24227 & 0.000967 & 0.006764 & 0.000031 \\
\hline STORY13 & 0.26884 & 0.001089 & 0.006692 & 0.000031 \\
\hline
\end{tabular}

\subsubsection{Capacity curve for CFT-RC frame}

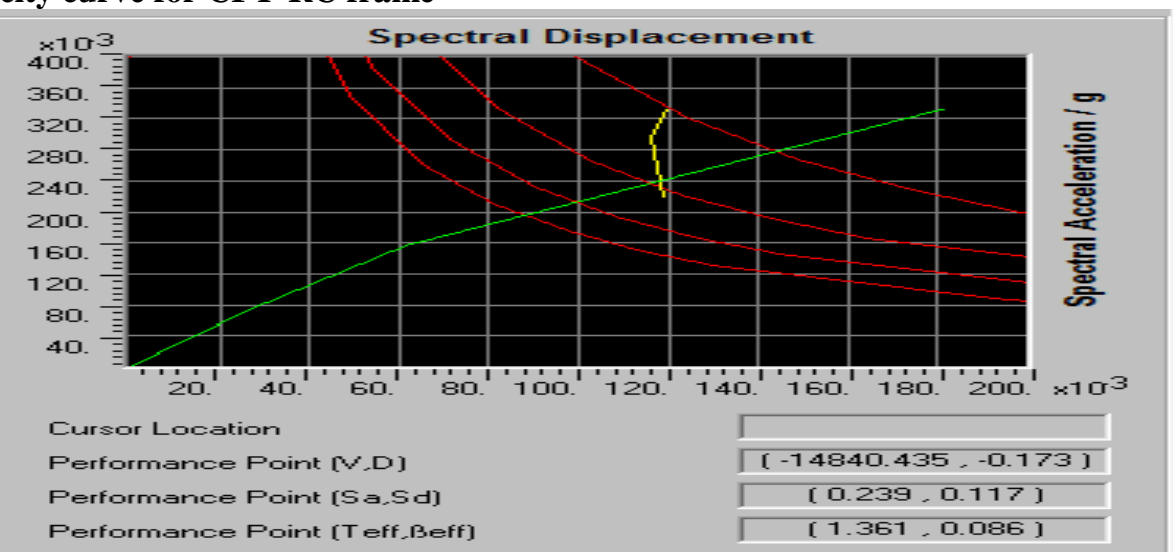

Fog.14. Capacity curve of FTS-RC beam

\subsubsection{3-D model of CFT-RC frame}

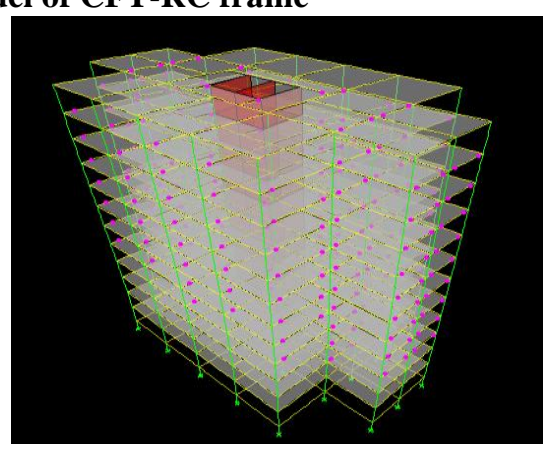

Fig.15. FTS-RC at elastic limit

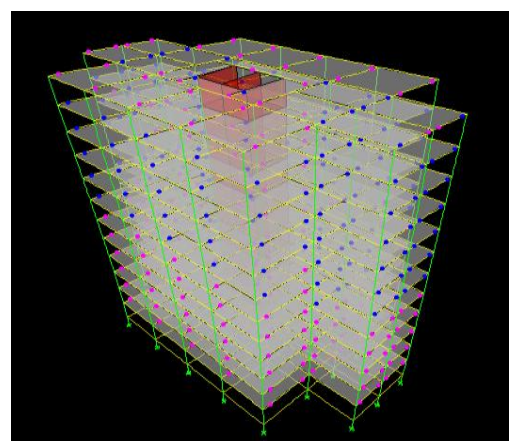

Fig.16. FTS-RC frame at yield point 
1.8. Comparative assessment of performance point and displacement for EIS-RC, ETS-RC, CFT-RC composite frame with RCC frame.

Table 6- Performance of composite \& RCC

\begin{tabular}{|l|l|l|}
\hline $\begin{array}{l}\text { TYPES OF } \\
\text { MODELS }\end{array}$ & $\begin{array}{l}\text { PERFORMA- } \\
\text { NCE POINT }\end{array}$ & $\begin{array}{l}\text { DISPLACEM- } \\
\text { ENT }(\mathrm{mm})\end{array}$ \\
\hline RCC & 14766.415 & 0.173 \\
\hline EIS-RC & 14909.314 & 0.172 \\
\hline FTS-RC & 14948.024 & 0.1709 \\
\hline ETS-RC & 14840.435 & 0.17 \\
\hline
\end{tabular}

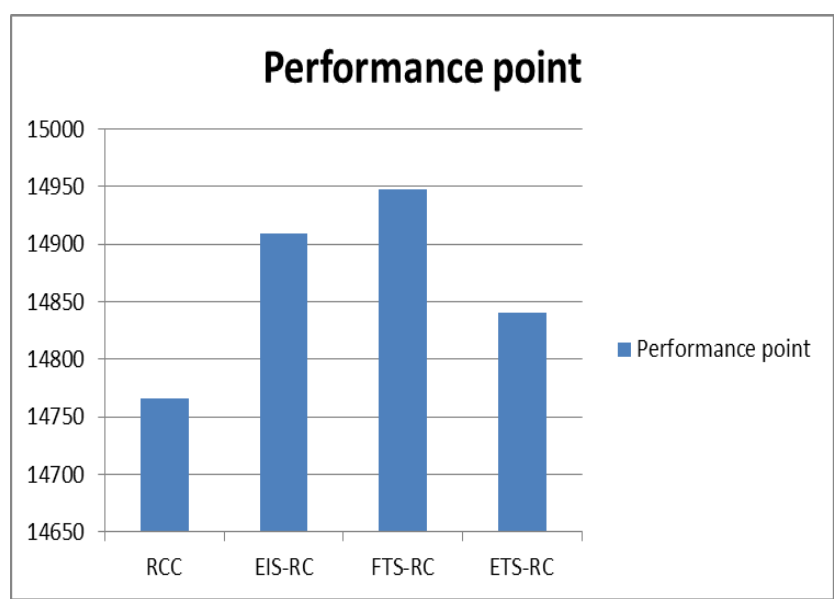

Fig.17. Performance Point of composite \& RCC

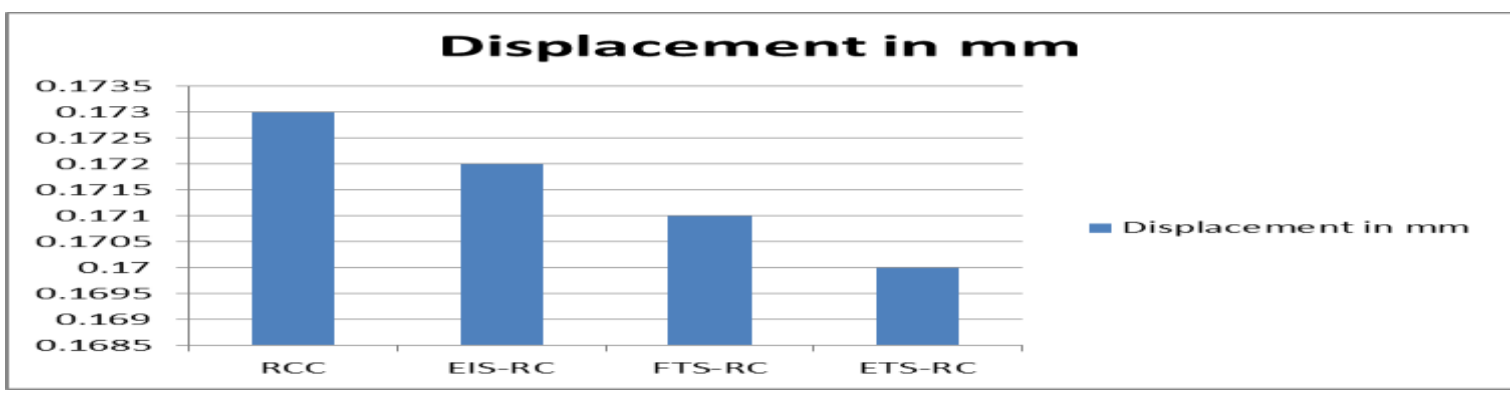

Fig.21 Performance Point (displacement) of composite \& RC frame

Table no. 6. Shows the comparative assessment of performance point value \& the displacement of RCC $\&$ composite frame. The fig. no. $17 \&$ fig. 18 . shows that the performance of composite is good as compare to RCC frame. From fig.17, it is seen that, the performance of composite is maximum and the displacement of composite frame is lesser as compared to the RCC frame respectively.

1.9. Result showing the comparison between self-weight, base shear in $\mathrm{X} \& \mathrm{Y}$ direction of RCCreinforced concrete section, EIS-RC, ETS-RC, CFT-RC frame.

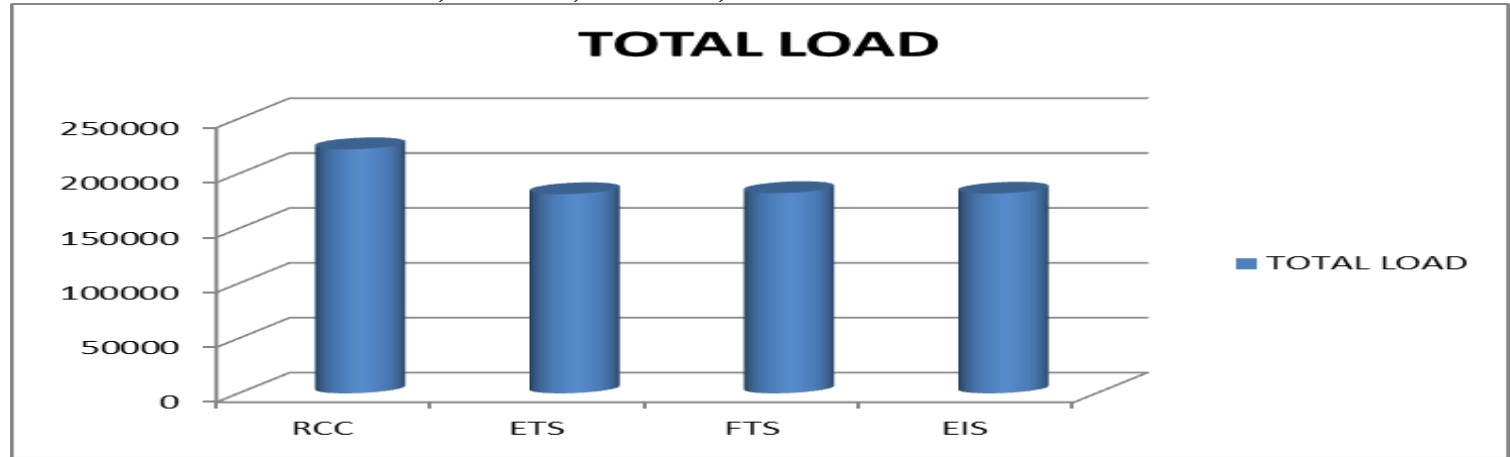

Fig.18.Variation of load (KN) 
IOSR Journal of Mechanical and Civil Engineering (IOSR-JMCE)

e-ISSN: 2278-1684,p-ISSN: 2320-334X, Volume 13, Issue 4 Ver. IV (Jul. - Aug. 2016), PP 22-32 www.iosrjournals.org

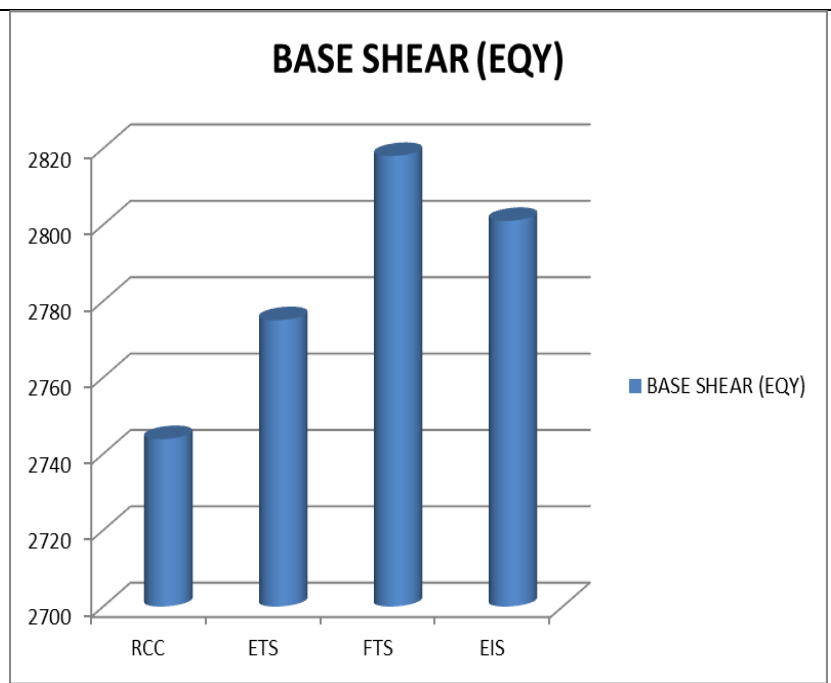

Fig.19. Comparison of base shear (KN) along Y-direction

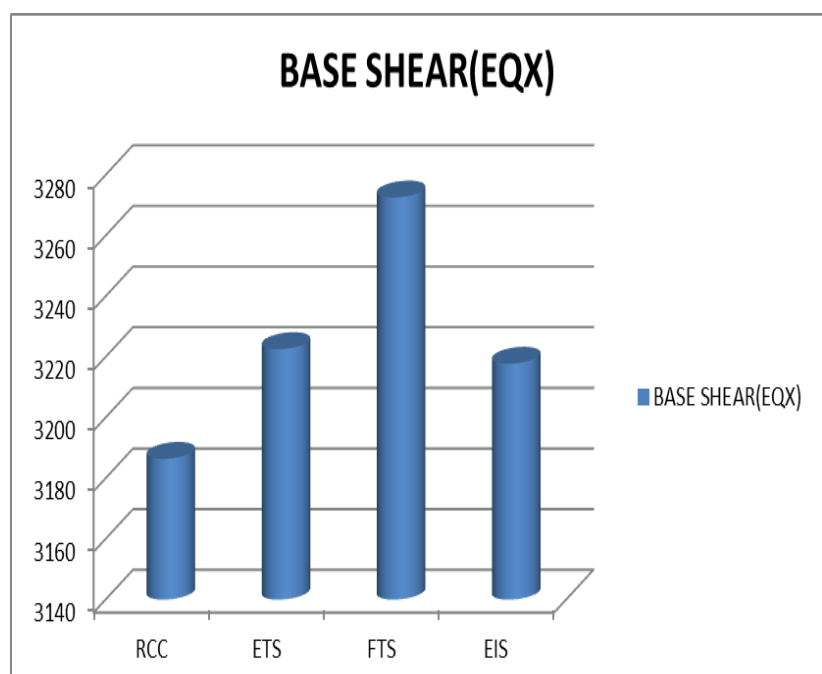

Fig..20. Comparison of base shear $(\mathrm{KN})$ along $\mathrm{X}$-direction

The comparison of story displacement \& story drift of Composite \& RCC frame.

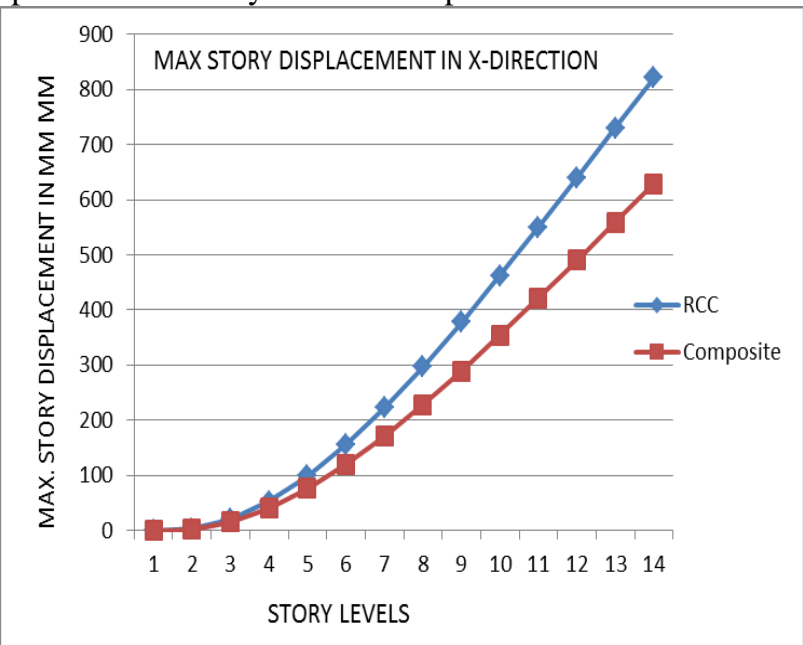

Fig..21. Maximum story displacement (mm) of RCC \& composite 


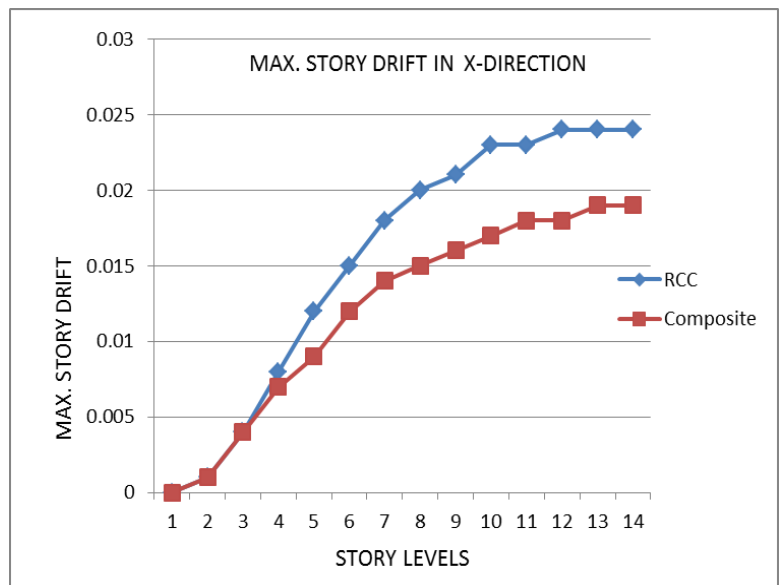

Fig.22. Maximum story drift (mm) of RCC \& composite

Fig. 18 shows that the self weight of the composite frame is reduced up to $30 \%$ as compared with RCC frame.likewise fig. 19 \& fig. 20 shows that the base shear of composite frame is maximum of $20-50 \%$ as compared to RCC frame.

From pushover analysis which represent in fig. 21 \& fig. 22; it is seen that, the story displacement of composite frame decreases upto $15-20 \%$ \& story drift of composite frame considerably reduced upto $5-10 \%$ as compared to RCC frame respectively.

\section{Conclusion}

From the above results and discussion it is concluded that the

1) Steel-concrete composite frame having more lateral load capacity compare to RCC frame.

2) The lateral displacement of steel-concrete composite frame is reduced as compared with RCC frame.

3) Steel-concrete composite frame follows strong column weak beam behaviour, as hinges are formed in beam element rather than column element.

4) Steel-concrete composite has light in weight as compared to RCC which gives ecnomical foundation design.

5) No unexpected plastic hinges were observed from inelastic analysis for both RCC \& composite frame. But yield mechanism of composite is superior to RCC.

6) Composite moment resisting frame has better performance in high seismicity as compared to RCC.

\section{Acknowledgements}

I would like to thank Prof. P M Kulkarni; guide \& P G coordinator, TCOER, Pisoli, Pune and Prof. Shingade V. S., HOD Civil Engg. Dept. of Trinity college of Engineering and Research, for constant encouragement and their valuable support. Also I am very grateful to my parents \& colleagues who are constantly encouraging me.

\section{References}

[1]. I.M. Castro, A.Y. Elghazouli and B.A. Izzuddin, Performance assessment of composite moment-resisting frames. 29th the 14 ${ }^{\text {th }}$ world conference on earthquake engineering, Beijing, China october 12-17, 2008,

[2]. Liu Jingbo and Liu Yangbing, Seismic behavior analysis of steel-concrete composite frame structure systems, The $14^{\text {th }}$ World Conference on Earthquake Engineering, Beijing, China, October 12-17, 2008,

[3]. Yangbing Liu, Yuanxin Liao \& Nina Zheng, Analysis of Strong Column and Weak Beam Behavior of Steel-concrete Mixed Frames, The $15^{\text {th }}$ World Conference on Earthquake Engineering, Lisboa,2012

[4]. Liang, Q. Hadi, M. N. (2008). Nonlinear analysis and behavior of concrete-filled steel tubular beam-columns. Structural Engineering and Construction Conference, London, (pp. 777-782),

[5]. Ricardo Herrera, Brian Lewis, James Ricles, Richard Sause, Experimental studies on steel moment resisting frames with concrete filled tube columns under earthquake loading conditions, $13^{\text {th }}$ World Conference on Earthquake Engineering, Vancouver, B.C., Canada, August 1-6, 2004 Paper No. 1591

[6]. QI Jing-jing, Jiang Li-zhong, Experimental study on seismic behaviors of steel-concrete composite frames, international journal on engineering, medical \& science, J. Cent. South Univ. (2015) 22: 4396-4413, DOI: 10.1007/s11771-015-2988-6.

[7]. J. Y. Richard Liew, Hong Chen, and N. E. Shanmugam, ASCE, Journal of Structural Engineering., 2001, 127(2)

[8]. Barbato, Michele, LSU, Nonlinear seismic response analysis of steel-concrete composite frames, Journal of Structural Engineering, 134(6), 01-01-2008,

[9]. M. Elchalakani, X.L. Zhao, R.H. Grzebieta, Concrete-filled circular steel tubes subjected to pure bending, Journal of Constructional Steel Research 57 (2001) 1141-1168,

[10]. Cui Chunyi, Zhao Jinfeng, Zhang Yannian and Zuo Wenxin, Experimental Analyses of Mechanical Performance of CFST Column to Assembled Steel H-Beam Connections, The Open Mechanical Engineering Journal, 2014, 8, 270-278,

[11]. Donglin Wang, Li Wang, Nonlinear Analysis of the New Composite Frame Structure, International Journal of Nonlinear Science Vol.11(2011) No.2 
[12]. Alessandro Zona; Michele Barbato; and Joel P. Conte, M.Asce, Nonlinear Seismic Response Analysis of Steel-Concrete Composite Frames, Journal of Structural Engineering, June 2008

[13]. Konstantinos Daniel Tsavdaridis, Seismic Analysis of Steel-Concrete Composite Buildings: Numerical Modeling, Encyclopedia of Earthquake Engineering, DOI 10.1007/978-3-642-36197-5,

[14]. G. Thermou, A.S. Elnashai, A. Plumier, Seismic design and performance of composite frames, Journal of Constructional Steel Research, January 2004 